\title{
Fragmented and Unclear Laws and Regulations of Foreign Direct Investment in Indonesian Tourism
}

\author{
I Gusti Ngurah Parikesit Widiatedja* and I Gusti Ngurah Wairocana** \\ DOI: https://doi.org/10.22304/pjih.v5n3.a1
}

Submitted: September 24, 2018 | Accepted: December 18, 2018

\begin{abstract}
Foreign direct investment has a crucial role in accelerating economic development of a state. One of the most attractive investment sectors is tourism that has unique characters of a service industry. It has contributed jobs, tax income, and domestic value significantly. However, foreign direct investment in tourism has adverse impacts, such as environmental and anti-competitive practice. The existence of domestic laws and regulations is crucial to determine a state's success to gain benefits from foreign direct investment in tourism. This paper aims to analyze the existing laws and regulations that regulate foreign direct investment in Indonesian tourism. This paper shows that the existence of foreign direct investment has been managed through fragmented and unclear laws and policies based on Indonesian laws of investment, tourism, environment, labor, and land.
\end{abstract}

Keywords: foreign direct investment, Indonesia, tourism regulations.

\section{Hukum Terfragmentasi dan Aturan yang Tidak Jelas terhadap Penanaman Modal Asing dalam Pariwisata Indonesia}

\begin{abstract}
Abstrak
Penanaman modal asing memiliki peran penting dalam meningkatkan pembangunan ekonomi di negara tuan rumah. Salah satu sektor penanaman modal asing yang paling menarik adalah pariwisata karena keunikan karakternya sebagai industri jasa. Penanaman modal asing di sector ini telah berkontribusi dalam menciptakan lapangan kerja, pajak, dan nilai tambah domestik. Namun, sector ini juga menyebabkan dampak negatif, seperti lingkungan dan praktik anti-persaingan. Memaksimalkan keuntungan dan sekaligus memitigasi dampak negatif, keberadaan hukum dan peraturan domestik sangat penting untuk menentukan sejauh mana keberhasilan suatu negara dalam memperoleh manfaat positif dari penanaman modal asing di sektor pariwisata. Tulisan ini bertujuan untuk menganalisis hukum dan peraturan terkait penanaman modal asing, khususnya pariwisata di Indonesia. Tulisan ini menunjukkan bahwa keberadaan penanaman modal asing dalam pariwisata dikelola melalui undang-undang dan kebijakan yang terfragmentasi dan cenderung mengandung ketidakjelasan dengan melihat undang-undang tentang investasi, pariwisata, lingkungan, tenaga kerja dan hak guna tanah di Indonesia.
\end{abstract}

Kata kunci: hukum pariwisata, Indonesia, penanaman modal asing

PADJADJARAN Journal of Law Volume 5 Number 3 Year 2018 [ISSN 2460-1543] [e-ISSN 2442-9325]

* Lecturer at Faculty of Law, Udayana University, Bali, Jalan Pulau Bali No. 1 Denpasar, ngurahparikesit@gmail.com, S.H., M.Hum. (Universitas Brawijaya), LL.M. (University of Washington), Ph.D Candidate (University of Melbourne).

** Professor of Law, Udayana University, Bali, the Dean of the Faculty of Law, Udayana University (2008-2016), Jalan Pulau Bali No. 1 Denpasar, wairocanangurah@yahoo.co.id, S.H. (Universitas Udayana), M.H., Dr. (Universitas Airlangga). 


\section{A. Introduction}

As a part of economic liberalization, foreign direct investment (FDI) is increasingly significant to boost economic development of a host country. Therefore, many countries arrange bilateral and multilateral agreements; open their markets to foreign investment; and remove burdensome of business processes. ${ }^{2}$

FDI has contributed excellence effects for a host country by providing jobs, ${ }^{3}$ enhancing productivity and export capacity; ${ }^{4}$ and escalating distribution channel for local companies. ${ }^{5}$ Likewise, in tourism sector, FDI has also promised more jobs because tourism has a more labor-created character than, for instance, agricultural fields. ${ }^{6}$ It allows more semi-skilled and low-skilled workers to get involved ${ }^{7}$ and carries reasonable rate served by the variety of its products. ${ }^{8}$ Other positive roles are related to the increase of tourism's value chain, ${ }^{9}$ government income, ${ }^{10}$ transfer of technology, ${ }^{11}$ and partnership with small and medium enterprises. ${ }^{12}$ Therefore, FDI in tourism has been one of important keys to solve the twin difficulties of joblessness and poverty in Indonesia. ${ }^{13}$ Despite the fact that it contributes important benefits, some studies denote negative impacts of FDI in tourism that include environmental issues ${ }^{14}$ and economic leakage. ${ }^{15}$

2 I Gusti Ngurah Parikesit Widiatedja, "Incorporating Local Wisdom into the Consumer Protection Legal Regime: A Comparison between Indonesia and Australia", Udayana Journal of Law and Culture, Vol. 1, No. 1, 2017, p. 32; see also I Gusti Ngurah Parikesit and I Gusti Ngurah Wairocana, "The Rise of the Spirit of National Interest and the Existence of World Trade Organization Agreement: A Case Study of Indonesia", Padjajaran Jurnal IImu Hukum, Vol. 4, No. 2, 2017, p. 335.

3 Julian Richards and Elizabeth Schaefer, "Jobs Attributable to Foreign Direct Investment in the United States", http://www.trade.gov/mas/ian/build/groups/public/@tg_ian/documents/webcontent/tg_ian_005496.pdf, downloaded on August 2018.

4 Jens M. Arnold and Beata S. Javorcik. "Gifted Kids or Pushy Parents? Foreign Direct Investment and Plant Productivity in Indonesia" Journal of International Economics, Vol. 79, 2009, p. 48

5 Huiya Chen and Deborah L. Swenson, "Multinational Exposure and the Quality of New Chinese Exports", Oxford Bulletin of Economics and Statistics, Vol. 76, 2014, p. 56.

6 Jonathan Mitchell and Caroline Ashley, Pathways to Prosperity - How Can Tourism Reduce Poverty: A Review of Pathways, Evidence and Methods, World Bank, 2007, p. 49.

7 United Nations Conference on Trade and Development, "The Contribution of Tourism to Trade and Development", http://unctad.org/en/Docs/cid8 en.pdf, downloaded on August 2018.

8 I Gusti Ngurah Parikesit Widiatedja, "Towards Liberalization of Services in ASEAN: Challenges and Opportunities of ASEAN Framework Agreement on Services (AFAS) on Tourism", Indonesian Journal of International Law, Vol. 10, No. 1, 2012, p. 67.

9 Jonathan Mitchell and Caroline Ashley, loc.cit., p. 127. Evridiki "Wsounta, Attracts to Parists to Paradise?", https://www.imf.org/external/pubs/ft/wp/2008/wp08277.pdf, downloaded on March 2018.

11 Peter Forsyth and Larry Dwyer, "Foreign Investment in Australian Tourism: A Framework for Analysis", The Journal of Tourism Studies, Vol. 14, 2003, p. 71.

12 Ibid.

13 I Gusti Ngurah Parikesit Widiatedja, "National Treatment Principle of General Agreement on Trade in Services (GATS) in Indonesia's Tourism Regulation" in Ni Ketut Supasti Dharmawan and I Made Budi Arsika (eds.), Sustainable Tourism and Law, The Hague: Eleven Publishing, 2013, p. 124.

14 Daniel Bodansky and Jessica C. Lawrence, "Trade and Environment" in Daniel Bethlehem, et.al., The Oxford Handbook of International Trade Law, Oxford: Oxford University Press, 2009, p. 511.

15 United Nations Conference on Trade and Development, "Sustainable tourism: Contribution to Economic Growth and Sustainable Development", http://unctad.org/meetings/en/SessionalDocuments/ciem5d2 en.pdf, downloaded on August 2018. 
Indonesia has issued laws and regulations to invite FDI in the field of tourism. It is expected that the investments will significantly determine the degree of Indonesia's success in gaining benefits of FDI in tourism. It is because FDI's benefits are not automatic. Clear and comprehensive national laws and policies must encourage these benefits. Unfortunately, Indonesia seems to manage FDI by fragmented and unclear laws and policies.

This paper aims to analyze the current Indonesian laws and regulations that standardize FDI in the field of tourism. This paper argues that the existence of FDI in tourism has been managed through fragmented-and-unclear laws and policies based on Indonesian laws on investment, tourism, environment, labor, and land.

This paper is started by the description of the existence of FDI. It covers definition, purposes, and types, as well as the government's efforts in encouraging FDI. Subsequently, it explains the existence of FDI in tourism, the growing importance of tourism, the unique character of tourism as a service industry, and the impact of FDI in Indonesian tourism. Finally, it analyses the Indonesia's laws and regulations on FDI of Tourism by observing investment-related laws and regulations on investment, tourism, environment, labor, and land in Indonesia.

\section{B. Literature Review of Foreign Direct Investment}

\section{The Definition and Theories of Foreign Direct Investment}

The International Monetary Fund (IMF) defined FDI as an investment process that is done to reach lasting interest in running beyond the investor's economy. ${ }^{16}$ Accordingly, the OECD explains FDI as a portion of cross-border investment in which a resident in one economy with the aim of gaining a lasting interest in enterprises resident in another economy. ${ }^{17}$ The lasting interest discusses to the existence of a long-term association between the direct investor and the enterprise. It also reveals a huge rate of influence of the direct investor on the enterprise's administration. The ownership of a-minimum-10-percent of voting rights, that show the role of investor, is the standard limit. ${ }^{18}$

FDI occurs within corporations (incorporated companies) or quasi-corporations (unincorporated companies running distinctly from their holders and that have, or for which it is potential to create, a distinct set of monetary accounts). A direct investment company is either a subsidiary (a controlled company if it is more than 50 percent held by its direct investor), an associate (an influenced company if it is between 10 and 50 percent held by its immediate direct investor) or a branch (a quasi-company). ${ }^{19}$

There is a theory justifying FDI by companies. John H. Dunning argues an "eclectic approach" in 1977. Three types of benefits -namely "ownership, location,

\footnotetext{
16 International Monetary Fund, "The Balance of Payments Manual", https://www.imf.org/external/np/sta/bop/BOPman.pdf, downloaded on August 2018.

17 The Organization for Economic Cooperation and Development (OECD), "OECD Benchmark Definition of Foreign Direct Investment", https://www.oecd.org/daf/inv/investmentstatisticsandanalysis/40193734.pdf, downloaded on August 2018.

18 Ibid.

19 Ibid.
} 
and internalization" - affected a company's willingness to expand production overseas. ${ }^{20}$ The ownership benefit is related to intangible aspects that cover the method of production, the capacity of entrepreneur, and the intellectual property rights. They could strengthen the competitive advantage of companies involving in FDI. ${ }^{21}$ The location benefit is related to aspects in a host country, including the presence of raw materials, wages' level, incentives, and policy of tax. ${ }^{22}$ Finally, the internalization benefit is related to actual participation in the production stage, instead of a contractual partnership, through a joint venture or licensing. ${ }^{23}$

Next, MacDougall (1960) explains that when the capital's movement occurs from a home country to a host country, capital's marginal productivity eventually will be equalized between two countries. ${ }^{24}$ Furthermore, Feldstein and Horioka (1980) elucidates that the capital's movement would mainly move from "capital-rich, lowinterest-rate" country to "higher-interest-rates and lower-capital-stock" country. ${ }^{25}$ This mechanism takes place until the interest rates and the capital stock had touched their equilibrium. ${ }^{26}$ After investing abroad, the home country's gain is received without any downward indication in the income of national as the home country has accepted higher benefits in the long period. ${ }^{27}$ Furthermore, the effects of spillovers of FDI encourages a country to invite FDI. In other words, these effects are related to the increase of domestic companies' productivity from the presence of foreign firms. ${ }^{28}$ Technological advancement, management skills, and working improvement are the illustrations of the kinds of spillovers. ${ }^{29}$

\section{How Government Encourage Foreign Direct Investment}

To maximize benefits and to mitigate negative impacts of FDI, countries issue laws, regulations, and policies to attract FDI. The measures differ according to their constitutions, national policy, and local situations. Under international law, a country has absolute right to control the acceptance and formation of foreign investors within its territory. ${ }^{30}$ Hence, a country has been entitled a free right as to the extent of open acceptance and the extent of rights of formation it considers fit to offer to foreign investors. ${ }^{31}$

\footnotetext{
John H. Dunning, The International Allocation of Economic Activity, London: Palgrave Macmillan, 1977, p. 63.

Ibid., p. 64.

Ibid., p. 69.

lbid., p. 107.

GDA MacDougall, "The Benefits and Costs of Private Investment from Abroad: A Theoretical Approach", Economic Record, Vol. 36, 1960, p. 32.

25 Martin Feldstein and Charles Horioka, "Domestic Savings and International Capital Flows", Economic Journal, Vol. 90, 1980, p. 315.

Ibid.

GDA MacDougall, op.cit., p. 27.

Molly Lesher and Sébastien Miroudot, "FDI Spillovers and their Interrelationships with Trade", OECD Trade Policy Working Paper No. 80, 2008, p. 7.

Ibid.

30 Peter Muchlinski, "Policy Issues" in Peter Muchlinski, Federico Ortino, Christoph Schreuer (eds.), The Oxford Handbook of International Investment Law, Oxford: Oxford University Press, 2008, p. 21.

31 Ibid.
} 
Furthermore, subject to its national laws and international agreements, a country is free to arrange entry and formation of FDI conditionally. ${ }^{32}$ On the other hand, controls over entry and formation, or conditional entry, are based on specific stipulations that must be scrutinized by the foreign investor. They could be based on the need to prioritize, among other things, national economic policy objectives, public order, national security, and public health. ${ }^{33}$

The OECD has recommended four main frameworks for domestic investment measure. ${ }^{34}$ Firstly, the government should issue a clear and comprehensive legal and regulatory structure of FDI. Next, it should assure that the laws and regulations, including their implementations, are transparent and consistent without imposing undue burdens. ${ }^{35}$ Then, the government should conduct policy flexibility; it is not only to pursue legal stability and predictability but also to intensify the role of investment to development. Finally, the government should involve all relevant stakeholders while issuing laws, policies, and regulations. ${ }^{36}$ The four basics framework could act as the 'minimum standard of treatment' commonly employed in international investment instruments, most often under the application of 'fair and equitable treatment'. ${ }^{37}$

Regarding land tenure, every government should issue comprehensive and accessible land legislations, and land administration should be transparent and efficient, explaining issues in relation to land rights administration, protection, and allocation at national and local levels. ${ }^{38}$ Concerning to enforcement and settlement mechanism, government should issue dispute settlement system that is effective and accessible to all investors, including SMEs and foreign investors. ${ }^{39}$ It also should establish alternative systems of to settle investment disputes. ${ }^{40}$

\section{Foreign Direct Investment on Tourism}

1. The Growing Importance of Tourism

Realizing the crucial role of tourism, almost every government is establishing innovative measures to create inclusive, competitive, and sustainable tourism development. Many countries consider an integrated method as a salient component of government framework. ${ }^{41}$ These integrated measures encourage the policy coherence and the effectiveness of public and/or private actions in tourism. ${ }^{42}$

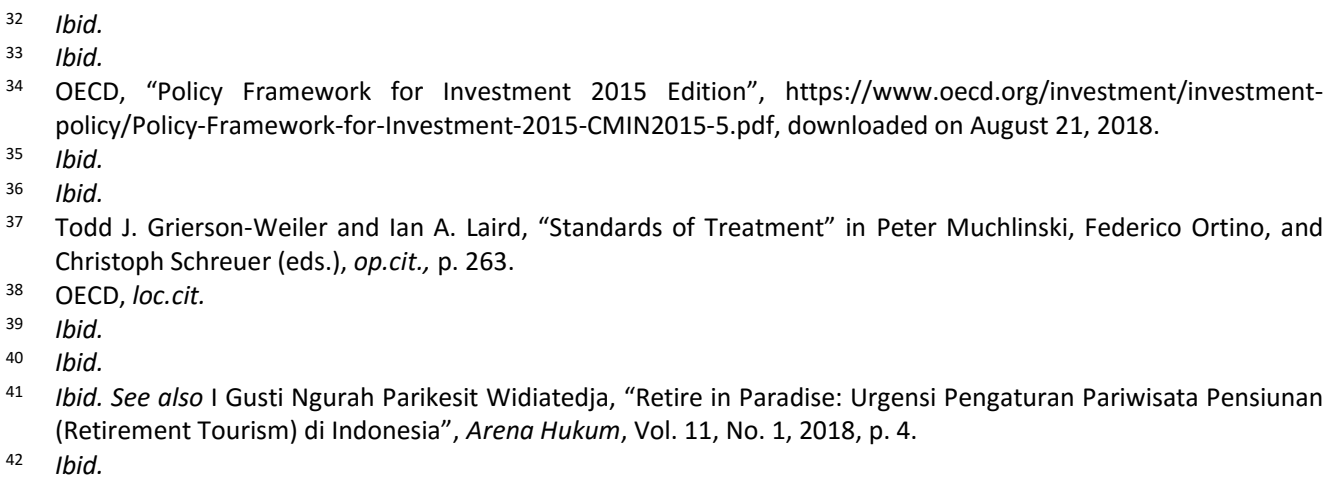


Universally, tourism has been an important role in economic activity, job creation, export revenue, and domestic value added. On average, tourism provides 4.1 percent of GDP, 5.9 percent of employment, and 21.3 percent of service exports to OECD countries. It is also predicted that around 80 percent of the tourism exports turn into domestic value added that is higher than the average of the total economy. ${ }^{43}$ Equally, international tourist arrivals reached 1.1 billion in 2014, an increase of 4.2 percent on the previous year. This figure is estimated to reach 1.8 billion by 2030, with international tourist arrivals in developing economy is predicted to increase at double compared to developed countries. ${ }^{44}$

\section{Unique Character of Tourism as a Business Sector}

According to some tourism scholars, as a services sector, tourism has several differences compared with other service sectors. ${ }^{45}$ Subsequently, from legal perspective, these unique differences may affect government in issue and implementation of law and policy. ${ }^{46}$

Tourism is intangible product of memory and experience that cannot be reproduced or reused. Its consumption also cannot be taken fully. ${ }^{47}$ Tourism is the combination of amenities and attractions in destination country, ${ }^{48}$ covering both tangible and intangible aspects such as accommodation, catering, entertainment, transportation, communication, and friendliness of local population, which are inseparable and complement each other. ${ }^{49}$

Economists argue that production is not perfect until the product finds the final consumer. Tourism is produced and consumed in the same place and the same time ${ }^{50}$ and is, therefore, perishable. ${ }^{51}$ All hotels with a fixed rooms and transport operators with a fixed number of seats face the challenge to match supply to available demand because surplus capacity on a particular day means a lost and it can never be recovered..$^{52}$ The next unique character of tourism is the seasonality of tourism demand. Demand of tourism products is characterized by an uneven temporal distribution. ${ }^{53}$ Annually, there are weeks and months with a great demand

43 Ibid.

44 United Nations World Tourism Organization, "UNWTO Tourism Highlights 2015 Edition", http://www.eunwto.org/doi/pdf/10.18111/9789284416899, downloaded on September 2018.

45 Arvid Flagestad and Christine A. Hope, "Scandinavian Winter: Antecedents, Concepts and Empirical Observations Underlying Destination Umbrella Branding Model", Tourism Review, Vol. 56, Issue 5, 2001, p. 12.

46 Annette Pritchard, Nigel J. Morgan, and Roger Pride Morgan, Destination Branding - Creating the Unique Destination Proposit ion, Oxford: Butterworth-Heinemann, 2002, p. 176.

47 Ibid.

48 Arthur John Burkart and S. Medlik, Tourism. Past, Present and Future, London: Heinemann, 1974, p. 206.

49 J.R. Brent Ritchie and Robin J.B. Ritchie, "The Branding of Tourism Destinations - Past Achievements and Future Challenges", A Basic Report Prepared for Presentation to the 1998 Annual Congress of the International Association of Scientific Experts in Tourism, http://citeseerx.ist.psu.edu/viewdoc/download?doi=10.1.1.201.9520\&rep=rep1\&type=pdf, downloaded on September 2018, pp. 111-119.

50 Peter U.C Dieke, "Tourism in Sub Saharan Africa: Production-Consumption Nexus", Current Issues Tourism, Vol. 16, 2013, p. 626.

51 J.R. Brent Ritchie and Robin J.B. Ritchie, loc.cit.

52 Norbert Vanhove, The Economic of Tourism Destination, Oxford: Elsevier Butterworth Heinemann, 2005, p. 14.

53 Ibid. 
and others with a low demand. This uneven distribution differs from country to country, and from destination to destination. ${ }^{54}$

The tourism industry relies on human resources. Specifically, the interaction between staff and customer defines the perception of quality. ${ }^{55}$ The attitude of staff is often a crucial element in serving tourism products. Another unique character of tourism is that the actors are in an unequal position. ${ }^{56}$ This fact is clearly visible, for example, with Disney World in Orlando, whereby one single company is overwhelmingly bigger than any of other companies. ${ }^{57}$

The final unique character of tourism is the interlinkages between tourism and other policy areas, including the economy, transportation, infrastructure, land use planning, local-and-regional development, and culture. Monetary policy that influences exchange rates can impact international visitor demand and foreign exchange earnings from the sector of tourism. ${ }^{58}$ Domestic tourism measures can encourage international demand a balance of trade payments. ${ }^{59} \mathrm{Next}$, transportation policy can be a tool to shift to more eco-friendly transport options. ${ }^{60}$

\section{The Positive and Negative Consequences of Foreign Direct Investment in Indonesian Tourism}

FDI in tourism field has a significant positive role in Indonesian economic growth and development. The presence of FDI has created job opportunities that are crucial to reduce unemployment and poverty. It has introduced world-class technology as well as technical know-how and processes that gradually improve the quality of tourism products. ${ }^{61}$ By enabling well-integrated training programs, FDI also has provided better quality human resources. Through joint ventures, FDI has been a positive trigger for new investors of tourism in Indonesia. Equally important, infrastructures, such as bridges, roads, airports, and public transport have developed to attract foreign investors. ${ }^{62}$

The presence of FDI in the field of tourism has some drawbacks. Foreign investors have given a significant economic influence on tourism development due to their capital domination in Bali. ${ }^{63}$ Numerous 'mega' tourism projects have been built in a concentrated area in Bali. ${ }^{64}$ This concentration has created a gap between

\footnotetext{
54 Ibid.

55 Jane Stacey, "Supporting Quality Jobs in Tourism", OECD Tourism Papers, February 2015, http://dx.doi.org/10.1787/5js4rv0g7szr-en, downloaded on August 2018.

56 J.R. Brent Ritchie and Robin J.B. Ritchie, op.cit., p. 25.

57 lbid.

58 Peter Haxton, "A Review of Effective Policies for Tourism Growth", OECD Tourism Papers, January 2015, http://dx.doi.org/10.1787/5js4vmp5n5r8-en, downloaded on August 2018.

59 Ibid.

60 Ibid.

61 I Gusti Ngurah Parikesit Widiatedja, Liberalisasi Pariwisata: Konstruksi Konsep, Ragam Masalah dan Alternatif Solusi, Denpasar: Udayana University Press, 2011, p. 78.

62 I Gusti Ngurah Parikesit Widiatedja, Liberalisasi Jasa dan Masa Depan Pariwisata Kita, Denpasar: Udayana University Press, 2010, p. 41.

63 Data from Indonesia Chamber of Commerce Chapter Badung, Bali, 2014.

64 It can be traced from the Data of Indonesia Statistic Bureau Chapter Bali that Revealed the Number of Hotel in Bali mostly located in Badung, Bali
} 
the rich in the southern, and the poor in the northern Bali. In northern Bali, many people still live under the poverty line with USD 2 per day income. ${ }^{65}$ Equally important, the benefits of conducting business in Indonesia do not always accrue to the local communities, but vanish to offshore accounts of foreign investors. The data from Indonesian Central Bank show that the Indonesian net investment position is in deficit. It mostly contributed by the largest component of the account balance in 2012. This fact could pose a threat to the balance of payments if the trade balance continues to shrink. One of the reasons of the deficit is that foreign-owned companies often decide to repatriate rather than reinvest their earnings. ${ }^{66}$

Uncontrolled tourism development has put enormous pressure on the environment. A study from the Ministry of Tourism along with International Labor Organization (2012) explains that there is a substantial rise of the consumption of water, energy, and waste's production after the attendance of hotels in some Indonesian tourism areas. ${ }^{67}$ In Bali, many hotels and villas that are owned by foreign investors are built on the lakeshore, riverbanks, ravines, hills, sacred, and coastal areas. ${ }^{68} \mathrm{~A}$ mangrove forest was also converted into economic zones to support the tourism industry. ${ }^{69}$ In addition, the availability of clean water (for both drinking and irrigation) has slumped, leading to damage to the physical structure of the soil. ${ }^{70}$ The rise of tourism has also triggered conversion of land from agricultural to nonagricultural uses. To date, 1,000 hectares of rice fields have been converted for commercial tourism activities. ${ }^{71}$ In Jakarta, hotels and other tourism facilities (that some of them are FDI) has led to the loss of coastal areas in Tidung Island, Kepulauan Seribu. ${ }^{72}$

\section{How Indonesia's Laws and Regulations Have Regulated Foreign Direct Investment on Tourism}

Prior to the discussion of Indonesia laws and regulations, this paper explains the importance of domestic laws and regulations in the management of FDI. In short, FDI's benefits are not automatic. The clear and comprehensive national laws and policies must bolster these benefits. Some leading scholars explained that the

65 Data from Indonesia Statistic Bureau Chapter Bali regarding Poverty Rate in Each Regency in Bali.

66 Bank Indonesia, "Statistic of Indonesia's Foreign Debt", Jakarta, 2012, p. 21.

67 Ministry of Tourism and Creative Economy of the Republic of Indonesia in cooperation with the International Labour Organization, Strategic Plan Sustainable Tourism and Green Jobs for Indonesia, Geneva: ILO, 2012, p. 23.

68 See, e.g., "Bali Must Stop Over Exploiting Environment Tourism: Activists," http://www.thejakartapost.com/news/2011/09/02/bali-must-stop-over-exploiting-environment-tourismactivists.html, downloaded on July 2018.

69 See, e.g., "Bali's Mangrove Forest May be Headed Toward Extinction," http://www.thejakartapost.com/news/2002/04/16/bali039s-mangrove-forests-may-be-headed-towardextinction.html, downloaded on July 2018.

70 See, e.g., "Turning Bali into Land of Gardens", http://m.thejakartapost.com/news/2007/01/16/turning-baliland-gardens.html, downloaded on July 2018.

71 Tjokorda Istri Putra Astiti, Anak Agung Istri Ari Atu Dewi, Michael Faure, "Tourism Development and Customary Land Law in Bali: The Case of the Tenganan Pagringsingan Village", Southwestern Journal of International Law, Vol. 20, 2013, p. 120.

72 Khrisnamurti, Heryanti Utami, and Rahmat Darmawan, “Dampak Pariwisata terhadap Lingkungan di Pulau Tidung Kepulauan Seribu”, Kajian, Vol. 21, No. 3, 2016, p. 257, p. 269. 
degree to which a country's failure or success to gain benefit from FDI is determined by the presence of national laws and policies. Hernando De Soto (2000) states that inefficiencies and formalities of the legal systems of developing countries have made them unable to gain capitalism's benefits. ${ }^{73}$ Trubek (2006) then shows how legal cultures of developing economies were greatly 'formalist', causing to weak enforcement, incongruous rules, and low-level legitimacy. ${ }^{74}$

Dee and Findlay (2009) and Abeysinghe (2014) subsequently point out that domestic laws and policies are more powerful than international laws in the sphere trade in services (such as tourism). The agreements of trade in services mostly cover "behind the border" regulatory barriers, while those on trade in goods mostly cover "at the border barriers" for instance tariffs. ${ }^{75}$ Specifically, a host country can carry out discriminatory limitations on the movement of capital (such as restrictions on foreign ownership), and a difference of domestic measures, for example, qualification force, licensing, and technical standards instead of tariffs. ${ }^{76}$ The discriminatory actions against FDI are still legal under the General Agreement on Trade in Services (GATS). From its launch, unlike other World Trade Organization (WTO) Agreements, a member does not have to obey with the whole GATS obligation. Specifically, GATS only binds WTO members when they have explicitly consent to be bound by GATS for a particular mode of supply or services. ${ }^{77}$

Some reports from international and non-governmental organizations (NGOs) indicate the drawbacks of legal systems in Indonesia. World Bank (2009) states that the lack of coordination across different branches of government, covering the central and local level, and across different ministries at the national level in formulating and implementing laws and policies has impeded the effectiveness of the government in realizing its development program. ${ }^{78}$ World Justice Project (2015) also raises three contributing factors for the shortcoming of law in Indonesia, namely 'defective investigations, an ineffective correctional system, and violations to due process of law'. ${ }^{79}$ The World Economic Forum (WEF)'s Global Competitiveness

73 Hernando De Soto, The Mystery of Capital: Why Capitalism Triumphs In The West and Fails Everywhere Else, London: Black Swan, 2000, p. 37.

74 David M Trubek, "The Rule of Law in Development Assistance: Past, Present, and Future" in David Trubek and Alvaro Santos (eds.), The New Law and Economic Development: A Critical Appraisal, Cambridge: Cambridge University Press, 2006, p. 76.

75 Philippa Dee and Christopher Findlay, "Services in PTAs - donuts or holes?" in Sisira Jayasuria, Donald MacLaren and Gary Magee (eds.), Negotiating a Preferential Trading Agreement: Issues, Constraints and Practical Options, Cheltenham: Edward Elgar, 2009, p. 98.

76 APC Subhashini Abeysinghe, "Services Trade in South Asia: the India-Sri Lanka CEPA" in Pierre Sauvé and Anirudh Shingal, The Preferential Liberalization of Trade in Services: Comparative Regionalism, Cheltenham: Edward Elgar, 2014, p. 312.

77 Peter Fuchs and Elisabeth Tuerk, "The General Agreement on Trade in Services (GATS) and current GATS Negotiations", Environmental Research of the Federal Ministry of the Environment, Nature Conservation and Nuclear Safety, Research Report 20019 1549, 2003, p. 6.

78 The World Bank, Indonesia Development Policy Review: Enhancing Government Effectiveness in a Democratic and Decentralized Indonesia, Washington DC: The World Bank, 2009, p. 16.

79 World Justice Project, Indonesia Country Report, Washington DC: World Justice Project, 2015, p. 24. 
Report 2016-2017 states that the most troublesome factors for conducting business in Indonesia were corruption and inefficiency in the bureaucracy of Indonesia. ${ }^{80}$

Indonesia has some laws that regulate tourism. Many of them reflect the poor FDI governance since they consist of fragmented laws and policies. In other words, Indonesia has not provided clear and comprehensive regulations to manage FDI, particularly in the field of tourism. Some important laws are explained in the following.

\section{Investment Law}

The first law that regulates the existence of FDI is the Law Number 25 of 2007 on Investment (Investment Law). Article 1(2) states that the objective of this law is to increase national economic growth. ${ }^{81}$ There have been some debates over the issuance of this law. First, in Article 22, this law has led to the haphazard opening of various sectors to foreign investors and allowing long-term land rights (up to 95 years) for foreigners, which is contradictory to the Indonesian constitution. ${ }^{82}$ Hence, the Constitutional Court of Indonesia, through the Decree Number 21, 22/PUUV/2007, dated March 25, 2008, had annulled the Article 22 from the Investment Law because of it. It contradicts the philosophical basis of the development of the Indonesian national economy. ${ }^{83}$ This situation has formed, to an extent, a vague law because Indonesia has not yet enacted a new model of Investment Law.

Article 3(1) of the Investment Law applies equal treatment to both FDI and local investor. ${ }^{84}$ This measure is somewhat debatable since Indonesia does not have to do so. Under GATS and WTO, it is still lawful to distinguish FDI and local investor, putting the latter as the priority for the sake of economic competitiveness. The equal treatment of FDI and local investor will likely put FDI, eventually, in the dominant position due to its unlimited fund, sophisticated technology, international link, and support from home country. National investors will have no chance to increase their competitiveness, particularly because almost all services sectors are opened for FDI.

In essence, host countries can and do impose discriminatory measures, which aims to regulate FDI within their territories. In pre-establishment phase, for example, host countries can issue domestic regulations in relation to technical, licensing, and qualification requirements for FDI that can be more burdensome. ${ }^{85}$ Furthermore, FDI can be subject to different taxes and may be repudiated access to particular subsidy programs. $^{86}$ In post-establishment phase, host countries can

80 Klaus Schwab (ed.), The Global Competitiveness Report 2016-2017, Geneva: World Economic Forum, 2017, p. 204.

81 Article 1(2) of Law Number 25 of 2007 on Capital Investment [Undang-Undang Nomor 25 Tahun 2007 tentang Penanaman Modal] (Investment Law).

82 Article 22 of Investment Law.

83 The Decision of the Constitutional Court of Indonesia No. 21, 22/PUU-V/2007, 25 March 2008 [Putusan Mahkamah Konstitusi No. 21/PUU-V/2007 tentang Pengujian UU No. 25 Tahun 2007 tentang Penanaman Modal].

84 Article 3(1) of Investment Law.

85 APC Subhashini Abeysinghe, op.cit., p. 312.

86 Ibid. 
impose a selection of performance requirements on FDI such as the duty to conduct training in managerial level positions. ${ }^{87}$ For instance, under the GATS, host countries have a great deal of discretion in determining the degree of openness of their liberalization process, taking into account of their economic development and domestic policy goals. ${ }^{88}$ Hence, they can unilaterally decide sectors to be opened or closed for FDI; limit foreign ownership in particular sectors; and impose additional obligations for FDI (such as the obligation to establish a joint venture company with local SMEs.

As an impact after ratifying WTO agreement, Indonesia always updates its negative investment list. According to the Elucidation of Presidential Regulation Number 44 of 2016, this list consists of business fields closed to investment and those that are opened to investment under certain conditions. ${ }^{89}$ Regarding service providers in tourism, the list of business fields closed to FDI and local investors in Indonesia encompasses public museums, historical and ancient heritage (temples, castles, epigraphy, remains, ancient buildings, etc.), residential/traditional environment, monuments, and gambling/casinos. A list of open business fields subject to conditions of investment can be clustered in several categories. Foreign service providers can operate and provide services through capital ownership from $51 \%{ }^{90}, 67 \%{ }^{91}$, to $100 \% .{ }^{92}$ All investors must comply location requirements and local regulations while managing business. This policy has escalated the Schedule of Specific Commitments of Indonesia that was promulgated in 1995 significantly.

Interestingly, Indonesia's list can be considered more liberal than other ASEAN countries. Thailand only allows no more than $49 \%$ of the presence of FDI on tourism through commercial presence. ${ }^{93}$ Malaysia only permits FDI in hotels that must not exceed $30 \%$ and $35 \%$ for four-star and five-star hotel, respectively. ${ }^{94}$ However, although Malaysia and Thailand open fewer tourism sectors and less type of transactions, they still have much higher number of tourist arrivals than Indonesia. ${ }^{95}$ Among ASEAN countries, Singapore is the only country that has fully liberalized its tourism sector. Nevertheless, Singapore is a developed country. Therefore, it is not a

87 Ibid.

88 Peter Fuchs and Elisabeth Tuerk, op.cit., p. 28.

89 Elucidation of Presidential Regulation Number 44 of 2016 on Lists of Business Fields that are Closed to and Business Fields that are Open with Conditions to Investment [Lampiran Peraturan Presiden Nomor 44 Tahun 2016 tentang Daftar Bidang Usaha yang Tertutup dan Bidang Usaha yang Terbuka dengan Persyaratan di Bidang Penanaman Modal].

90 For example: Spa

91 For example: one-star hotel, two star hotel, private museum, art gallery.

92 For example: Bars, cafes, restaurants, four-star hotel, five-star hotel.

93 See also The Secretariat of ASEAN, "Schedule of Specific Commitments of Thailand", http://www.aseansec.org/economic/ services/2nd tha.pdf, downloaded on May 2018.

See also The Secretariat of ASEAN, "Schedule of Specific Commitments of Malaysia" http://www.aseansec.org/economic/ services/2nd_mal.pdf, downloaded on May 2018.

95 The Data from World Tourism Organization in International Tourist Arrivals showed that the number of tourist arrivals in Thailand was 26.5 million and Malaysia 25.7 million. Meanwhile, only 8.8 million tourist visited Indonesia in 2013. See United Nations World Tourism Organization, "Tourism Highlight 2014", http://www.eunwto.org/doi/pdf/10.18111/9789284416226, downloaded on July 2018. 
fair comparison for Indonesia, which is facing many tourism problems. Indonesia should not open all sectors for FDI based on Singapore's standards.

Moreover, the lack of coordination between central and local governments has affected FDI governance. Ewing-Chow and Losari (2015) state that foreign investors had to acquire some licenses in which investment agency in central and local levels share their roles and responsibilities over the issuance of these licenses. ${ }^{96} \mathrm{~A}$ local government has ever rejected to approve an application of a license although the foreign investor had secured in-principle consent from the central government. ${ }^{97}$

\section{Tourism Law}

Pertaining to Law Number 10 of 2009 on Tourism (Tourism Law), although Article 2 of the law has recognized non-discrimination principle and right to tourism, the content has not yet adopted the tourism's perspective as a service, including all of tourism's uniqueness. ${ }^{98}$ There are no articles in the law that clearly indicates how tourism must be viewed as a service instead of ordinary economic activities. According to Article 5, this law predominantly referred to Global Code Ethic for Tourism from United Nations World Tourism Organization (UNWTO) although there is no requirement to adopt this code. ${ }^{99}$ Indonesia's Tourism Law is supposed to adopt GATS as a result of WTO Agreement ratification. Equally important, the classification of tourism sectors in the Tourism Law does not follow the classification from GATS. Specifically, while GATS put tourism and recreational services as a different category, Indonesia's Tourism Law put recreational services as a part of tourism.

\section{Environmental Law}

The Law Number 32 of 2009 on Environmental Protection and Management (Environmental Law) also regulates the existence of FDI. However, this law has some drawbacks. Waddell (2004) points out that the environmental law in Indonesia is 'ineffective' or even 'dysfunctional' due to the high level of non-compliance caused by insufficient administrative and criminal sanctions. ${ }^{100} \mathrm{~A}$ study from the University of Gothenburg (2008) explains the unclear mandates between central and local governments that led to the overlap of and contradictory environmental

96 Michael Ewing-Chow and Junianto James Losari, "Multiple Authorisation: the Legal Complexity of Desentralisasi in Indonesia and the Potential Contribution of IIAs in Reducing Confusion", Indonesia Law Review, Vol. 3, 2015, p. 247.

97 Ibid.

98 Article 2 of Law Number 10 of 2009 on Tourism [Undang-Undang Nomor 10 Tahun 2009 tentang Kepariwisataan] (Tourism Law).

99 Article 5 of Tourism Law.

100 SK Waddell, The Role of the Legal Rule in Indonesian Law: Environmental Law and Reformasi of Water Quality Management, Sydney: University of Sydney, 2004, p. xxii. 
regulations. ${ }^{101}$ In addition, Sumardjono et al (2011) identifies 12 environmentalrelated laws that overlap each other and are inharmonious one another. ${ }^{102}$

One of the main concerns related to the Environmental Law is the procedure of Environmental Impact Assessment (EIA). Article 1(11) of the Environmental Law states that EIA is a study of the significant impact of a particular activity on the environment that is undertaken in the planning stages and it will be used as the legal basis to decide whether such activity will adversely affect the environment. ${ }^{103}$ After passing the EIA, Article 36 regulates a company that intends to start a business or expand its business is eligible to proceed an environmental license. ${ }^{104}$ According to Article 40 , once the government has granted an environmental license, then a company can apply for a commercial license as a means of legalizing its business in Indonesia. ${ }^{105}$ In other words, the Environmental Law prohibits a company to start or to expand its business before conducting the EIA. However, many companies, which have not conducted yet the EIA, receive a commercial license and start their business.

In December 2016, the Ministry of Environment and Forestry issued a Ministerial Decree Number P.102/Menlhk/Setjen/kum.1/12/2016 on the Guidelines for the Arrangement of Environmental Evaluation Documents for Companies that Have Commercial Licenses but Not Have Environmental Documents. It acknowledges this fact and then require companies to proceed 'Environmental Evaluation Documents' as a replacement step of the EIA. ${ }^{106}$ The Environmental Law, according to Article 109(1), also imposes criminal sanctions for any person or company conducting business without an environmental license, ${ }^{107}$ and for authorized officers who issues a commercial license without being equipped with the EIA following Article $111(2) .{ }^{108}$ However, the fact that many companies have started their business

101 Gunilla Ölund Wingqvist and Emelie Dahlberg, Indonesia Environmental and Climate Change Policy Brief, Gothenburg: School of Business, 2008, p. 5, see also Ida Nurlinda, Prinsip-Prinsip Pembaruan Agraria: Perspektif Hukum, Jakarta: Rajawali Pers, 2009, p. 162.

102 Maria SW Sumardjono (et.al.), Pengaturan Sumber Daya Alam di Indonesia Antara Yang Tersurat dan Tersirat, Kajian Kritis Undang-undang Terkait Penataan Ruang dan Sumber Daya Alam, Yogyakarta: Gadjah Mada University Press, 2011, p. 51. These laws are the Law Number 32 of 2009 on the Environmental Protection and Management, the Law Number 5 of 1960 on Land, the Law Number 5 of 1990 on Vital Natural Resource Conservation and Its Ecosystem, the Law Number 41 of 1999 on Forestry, the Law Number 22 of 2001 on Petroleum and Natural Gas, the Law Number 27 of 2003 on Earth Heat, the Law Number 7 of 2004 on Water Resources, the Law Number 31 of 2004 on Fishery, the Law Number 26 of 2007 on Spatial Layout, the Law Number 27 of 2007 on the Management of Coastal Areas and Small Islands, the Law Number 18 of 2008 on the Management of Garbage and the Law Number 4 of 2009 on Mineral and Coal Mining.

103 Article 1(11) of Law Number 32 of 2009 on Environmental Protection and Management [Undang-Undang Nomor 32 Tahun 2009 Tentang Perlindungan dan Pengelolaan Lingkungan Hidup](Environmental Law).

104 Article 36 of Environmental Law.

105 Article 40 of Environmental Law.

106 The Consideration of The Ministry of Environment and Forestry Decree No P.102/Menlhk/Setjen/kum.1/12/2016 on Guidelines for the Arrangement of Environmental Evaluation Documents for Companies that Have Commercial Licenses but Not Have Environmental Documents [Bagian Menimbang Peraturan Menteri Lingkungan Hidup dan Kehutanan Republik Indonesia Nomor P.102/Menlhk/Setjen/kum.1/12/2016 Tentang Pedoman Penyusunan Dokumen Lingkungan Hidup Bagi Usaha dan/atau Kegiatan Yang Telah Memiliki Izin Usaha dan/atau Kegiatan Tetapi Belum Memiliki Dokumen Lingkungan Hidup].

107 Article 109(1) of Environmental Law.

108 Article 111(2) of Environmental Law. 
without conducting the EIA indicates the lack of the implementation and the enforcement of Environmental Law, especially in the EIA mechanism. In this scenario, foreign hotel companies could operate in Bali without conducting the EIA. Although the government require these hotels to conduct the EIA later, it would be too late or even useless if the environmental damages have already occurred. This situation can be getting worse due to the fact that the lack of environmental concern under Indonesia's investment treaties. ${ }^{109}$

\section{Labor and Land Laws}

The Investment Law regulates that, while recruiting employee, FDI companies shall prioritize Indonesian. Foreign employee can only be posted in certain positions that require special expertise. According to Article 10 of the Investment Law, they should increase the capability of Indonesian employees' vocational training. ${ }^{110}$ Article 42 of the Law Number 13 of 2003 on Manpower then elucidates some stipulations that must be complied while inviting foreign workers (expatriates). They include a written license from the authorized ministry. Individual employers are prohibited to recruit expatriates. Thus, expatriates can be employed in Indonesia only for particular position and period. ${ }^{111}$

Although foreign workers can only be employed for a particular position and period, and the position shall be related to the existence of FDI, the facts are different. Tourism is one of the most attractive sectors that invite low-level-skill foreign workers. ${ }^{112}$ Some hotels in Bali employ foreigner with low-level skills. ${ }^{113}$ The common practice that have been happening since the last ten years is that the existence of foreigner (who use tourist visa) work as a guide for tourists who come from similar home country. ${ }^{114}$

Under Article 9 of the Law Number 5 of 1960 on Basic Agrarian Law, only Indonesian citizens are allowed to have right of ownership (hak milik). Foreigners have three eligible rights, namely right of use (hak pakai), leasehold (hak guna usaha), and building rights (hak guna bangunan). ${ }^{115}$ In other words, foreigners (both individuals and companies) do not have the right of ownership. However, there has

\footnotetext{
109 I Gusti Ngurah Parikesit Widiatedja and I Gusti Ngurah Wairocana, "The Lack of the Environmental Concern in Indonesia's Bilateral Investment Treaties", Hasanuddin Law Review, Vol. 3, No. 3, 2017, p. 242.

110 Article 10 of Investment Law.

111 Article 42 of Law Number 13 of 2003 on Manpower [Undang-Undang Nomor 13 Tahun 2003 tentang Ketenagakerjaan].

112 Achmad Dwi Afriyadi, "KSPI: TKA Kasar Masuk RI Paling Banyak di Sektor Pariwisata", https://finance.detik.com/berita-ekonomi-bisnis/d-3999587/kspi-tka-kasar-masuk-ri-paling-banyak-di-sektorpariwisata, downloaded on September 2018.

113 Wayan Surnantaka, "Ancaman Tenaga Asing Mulai Melanda Sektor Pariwisata di Bali", https://www.posbali.id/ancaman-tenaga-asing-mulai-melanda-sektor-pariwisata-di-bali/, downloaded on September 2018.

114 News Okezone, "Tenaga Kerja Asing llegal Berkedok Wisatawan Merajalela di Bali", https://news.okezone.com/read/2014/04/13/340/969534/tenaga-kerja-asing-ilegal-berkedok-wisatawanmerajalela-di-bali, downloaded on September 2018.

115 Article 9 of Law Number 5 of 1960 on Basic Agrarian Law [Undang-Undang Nomor 5 Tahun 1960 Tentang Undang-Undang Pokok Agraria].
} 
been a common clandestine practice, particularly in tourism area, where a foreigner buys a land by using an Indonesian name so to get the right of ownership. To bind both parties (foreigner and Indonesian), they made other related agreements, such as debt recognition deed, explaining foreigner lends money to Indonesian, and the land purchased is employed as collateral for ensuring Indonesian's debt. Although this practice does not violate any existing rules in Indonesia, there has been a transfer of property rights in this practice, making a foreigner able to take a control over Indonesian land.

\section{E. Conclusion}

The governance of FDI in Indonesia is managed through fragmented and unclear laws and policies. Specifically, the Investment Law has led to the haphazard opening of various sectors to foreign investors and allowing long-term land rights (up to ninety-five years) for foreigners, which is in conflict with the Indonesian constitution. Moreover, it applies the equal treatment between FDI and local investor although Indonesia does not have to do so according to WTO and GATS. In essence, host countries can impose discriminatory measures aimed at regulating the FDI within their territories. In addition, the investment in Indonesia is too liberal, compared to other ASEAN countries. Equally important, the lack of coordination between central and local governments has also affected the FDI governance.

The content of the tourism law has not yet adopted the tourism's perspective as trade in services, including all tourism's uniqueness. In the side of environmental law, there has been a debate in relation to low-level of compliance in EIA governance. Specifically, many companies have received a commercial license, and then have started their business although they have not conducted yet the EIA. On the other hand, in the side of the labor law, the lack of enforcement has made tourism to be one of the most attractive sectors that invite low-level skill of foreign workers. For these reasons, the existing land governance has not been able to avoid the clandestine practice. For example, a foreigner may use Indonesian people's name to get "the real" right of ownership within Indonesia's territory.

\section{References}

\section{Books}

Bethlehem, Daniel, et.al., The Oxford Handbook of International Trade Law, Oxford University Press, Oxford, 2009.

Burkart, Arthur John, and S. Medlik, Tourism. Past, Present and Future, Heinemann, London, 1974.

De Soto, Hernando, The Mystery of Capital: Why Capitalism Triumphs In The West and Fails Everywhere Else, Black Swan, London, 2000.

I Gusti Ngurah Parikesit Widiatedja, Liberalisasi Jasa dan Masa Depan Pariwisata Kita, Udayana University Press, Denpasar, 2010. 
Ida Nurlinda, Prinsip-Prinsip Pembaruan Agraria: Perspektif Hukum, Rajawali Pers, Jakarta, 2009.

Jayasuria, Sisira, Donald MacLaren and Gary Magee (eds.), Negotiating a Preferential Trading Agreement: Issues, Constraints and Practical Options, Edward Elgar, Cheltenham, 2009.

Maria SW Sumardjono (et.al.), Pengaturan Sumber Daya Alam di Indonesia Antara Yang Tersurat dan Tersirat, Kajian Kritis Undang-undang Terkait Penataan Ruang dan Sumber Daya Alam, Gadjah Mada University Press, Yogyakarta, 2011.

Ministry of Tourism and Creative Economy of the Republic of Indonesia in cooperation with the International Labour Organization, Strategic Plan Sustainable Tourism and Green Jobs for Indonesia, ILO, Geneva, 2012.

Ni Ketut Supasti Dharmawan and I Made Budi Arsika (eds.), Sustainable Tourism and Law, Eleven Publishing, The Hague, 2013.

Pritchard, Annette, Nigel J. Morgan, and Roger Pride Morgan, Destination Branding Creating the Unique Destination Proposition, Butterworth-Heinemann, Oxford, 2002.

Sauvé, Pierre, and Anirudh Shingal, The Preferential Liberalization of Trade in Services: Comparative Regionalism, Edward Elgar, Cheltenham, 2014.

Schwab, Klaus (ed.), The Global Competitiveness Report 2016-2017, World Economic Forum, Geneva, 2017.

The World Bank, Indonesia Development Policy Review: Enhancing Government Effectiveness in a Democratic and Decentralized Indonesia, The World Bank, Washington DC, 2009.

Trubek, David, and Alvaro Santos (eds.), The New Law and Economic Development: A Critical Appraisal, Cambridge University Press, Cambridge, 2006.

Vanhove, Norbert, The Economic of Tourism Destination, Elsevier Butterworth Heinemann, Oxford, 2005.

Waddell, SK, The Role of the Legal Rule in Indonesian Law: Environmental Law and Reformasi of Water Quality Management, University of Sydney, Sydney, 2004.

Wingqvist, Gunilla Ölund, and Emelie Dahlberg, Indonesia Environmental and Climate Change Policy Brief, School of Business, Gothenburg, 2008.

World Justice Project, Indonesia Country Report, World Justice Project, Washington DC, 2015.

\section{Other Documents}

Achmad Dwi Afriyadi, "KSPI: TKA Kasar Masuk RI Paling Banyak di Sektor Pariwisata", https://finance.detik.com/berita-ekonomi-bisnis/d-3999587/kspi-tka-kasarmasuk-ri-paling-banyak-di-sektor-pariwisata, downloaded on September 2018

Arnold, Jens M., and Beata S. Javorcik, "Gifted Kids or Pushy Parents? Foreign Direct Investment and Plant Productivity in Indonesia" Journal of International Economics, Vol. 79, 2009.

Bank Indonesia, "Statistic of Indonesia's Foreign Debt", Jakarta, 2012.

Brent Ritchie, J.R., and Robin J.B. Ritchie, "The Branding of Tourism Destinations Past Achievements and Future Challenges", A Basic Report Prepared for 
Presentation to the 1998 Annual Congress of the International Association of Scientific Experts in Tourism, http://citeseerx.ist.psu.edu/viewdoc/download?doi=10.1.1.201.9520\&rep=rep1 \&type=pdf, downloaded on September 2018.

Chen, Huiya and Deborah L. Swenson, "Multinational Exposure and the Quality of New Chinese Exports", Oxford Bulletin of Economics and Statistics, Vol. 76, 2014. Chow, Michael Ewing and Junianto James Losari, "Multiple Authorisation: the Legal Complexity of Desentralisasi in Indonesia and the Potential Contribution of IIAS in Reducing Confusion", Indonesia Law Review, Vol. 3, 2015.

Dieke, Peter U.C., "Tourism in Sub Saharan Africa: Production-Consumption Nexus", Current Issues Tourism, Vol. 16, 2013.

Feldstein, Martin, and Charles Horioka, "Domestic Savings and International Capital Flows", Economic Journal, Vol. 90, 1980.

Flagestad, Arvid and Christine A. Hope, "Scandinavian Winter: Antecedents, Concepts and Empirical Observations Underlying Destination Umbrella Branding Model", Tourism Review, Vol. 56, Issue 5, 2001.

Forsyth, Peter and Larry Dwyer, "Foreign Investment in Australian Tourism: A Framework for Analysis", The Journal of Tourism Studies, Vol. 14, 2003.

Fuchs, Peter, and Elisabeth Tuerk, "The General Agreement on Trade in Services (GATS) and current GATS Negotiations", Environmental Research of the Federal Ministry of the Environment, Nature Conservation and Nuclear Safety, Research Report 20019 1549, 2003.

Haxton, Peter, "A Review of Effective Policies for Tourism Growth", OECD Tourism Papers, January 2015, http://dx.doi.org/10.1787/5js4vmp5n5r8-en, downloaded on August 2018.

I Gusti Ngurah Parikesit and I Gusti Ngurah Wairocana, "The Rise of the Spirit of National Interest and the Existence of World Trade Organization Agreement: A Case Study of Indonesia", Padjajaran Jurnal IImu Hukum, Vol. 4, No. 2, 2017.

Environmental Concern in Indonesia's Bilateral Investment Treaties", Hasanuddin Law Review, Vol. 3, No. 3, 2017.

I Gusti Ngurah Parikesit Widiatedja, "Incorporating Local Wisdom into the Consumer Protection Legal Regime: A Comparison between Indonesia and Australia", Udayana Journal of Law and Culture, Vol. 1, No. 1, 2017.

"Retire in Paradise: Urgensi Pengaturan

Pariwisata Pensiunan (Retirement Tourism) di Indonesia", Arena Hukum, Vol. 11, No. 1, 2018.

ASEAN: Challenges and Opportunities of ASEAN Framework Agreement on Services (AFAS) on Tourism", Indonesian Journal of International Law, Vol. 10, No. 1, 2012.

International Monetary Fund, "The Balance of Payments Manual", https://www.imf.org/external/np/sta/bop/BOPman.pdf, downloaded on August 2018. 
Khrisnamurti, Heryanti Utami, and Rahmat Darmawan, "Dampak Pariwisata terhadap Lingkungan di Pulau Tidung Kepulauan Seribu", Kajian, Vol. 21, No. 3, 2016.

Lesher, Molly and Sébastien Miroudot, "FDI Spillovers and their Interrelationships with Trade", OECD Trade Policy Working Paper No. 80, 2008.

MacDougall, GDA., "The Benefits and Costs of Private Investment from Abroad: A Theoretical Approach", Economic Record, Vol. 36, 1960.

Mitchell, Jonathan and Caroline Ashley, Pathways to Prosperity - How Can Tourism Reduce Poverty: A Review of Pathways, Evidence and Methods, World Bank, 2007.

Muchlinski, Peter, Federico Ortino, and Christoph Schreuer (eds.), The Oxford Handbook of International Investment Law, Oxford University Press, Oxford, 2008

News Okezone, "Tenaga Kerja Asing llegal Berkedok Wisatawan Merajalela di Bali", https://news.okezone.com/read/2014/04/13/340/969534/tenagakerja-asing-ilegal-berkedok-wisatawan-merajalela-di-bali, downloaded on September 2018.

Richards, Julian, and Elizabeth Schaefer, "Jobs Attributable to Foreign Direct Investment in the United States", http://www.trade.gov/mas/ian/build/groups/public/@tg ian/documents/webc ontent/tg ian 005496.pdf, downloaded on August 2018.

Stacey, Jane, "Supporting Quality Jobs in Tourism", OECD Tourism Papers, February 2015, http://dx.doi.org/10.1787/5js4rv0g7szr-en, downloaded on August 2018.

The Jakarta Post, "Bali Must Stop Over Exploiting Environment Tourism: Activists," http://www.thejakartapost.com/news/2011/09/02/bali-must-stop-overexploiting-environment-tourism-activists.html, downloaded on July 2018.

$\begin{aligned} & \text { Extinction," } \\ & \text { mangrove-forests-may-be-headed-toward-extinction.html, downloaded on July } \\ & \text { http://www.thejakartapost.com/news/2002/04/16/bali039s- }\end{aligned}$
2018.
http://m.thejakartapost.com/news/2007/01/16/turning-bali-land-gardens.html,
downloaded on July 2018.

The Organization for Economic Cooperation and Development (OECD), "OECD Benchmark Definition of Foreign Direct Investment", https://www.oecd.org/daf/inv/investmentstatisticsandanalysis/40193734.pdf, downloaded on August 2018.

The Secretariat of ASEAN, "Schedule of Specific Commitments of Thailand", http://www.aseansec.org/economic/ services/2nd tha.pdf, downloaded on May 2018.

Tjokorda Istri Putra Astiti, Anak Agung Istri Ari Atu Dewi, Michael Faure, "Tourism Development and Customary Land Law in Bali: The Case of the Tenganan Pagringsingan Village", Southwestern Journal of International Law, Vol. 20, 2013. 
Tsounta, Evridiki, "What Attracts Tourists to Paradise?", https://www.imf.org/external/pubs/ft/wp/2008/wp08277.pdf, downloaded on March 2018.

United Nations Conference on Trade and Development, "Sustainable tourism: Contribution to Economic Growth and Sustainable Development", http://unctad.org/meetings/en/SessionalDocuments/ciem5d2 en.pdf, downloaded on August 2018.

United Nations Conference on Trade and Development, "The Contribution of Tourism to Trade and Development", http://unctad.org/en/Docs/cid8 en.pdf, downloaded on August 2018.

United Nations World Tourism Organization, "Tourism Highlight 2014", http://www.e-unwto.org/doi/pdf/10.18111/9789284416226, downloaded on July 2018.

Edition", $\quad$ http://www.e-unwto.org/doi/pdf/10.18111/9789284416899, downloaded on September 2018.

Wayan Surnantaka, "Ancaman Tenaga Asing Mulai Melanda Sektor Pariwisata di Bali", https://www.posbali.id/ancaman-tenaga-asing-mulai-melanda-sektorpariwisata-di-bali/, downloaded on September 2018.

\section{Legal Documents}

Law Number 5 of 1960 on Basic Agrarian Law [Undang-Undang Nomor 5 Tahun 1960 tentang Undang-Undang Pokok Agraria].

Law Number 25 of 2007 on Capital Investment [Undang-Undang Nomor 25 Tahun 2007 tentang Penanaman Modal].

Law Number 10 of 2009 on Tourism [Undang-Undang Nomor 10 Tahun 2009 tentang Kepariwisataan].

Law Number 32 of 2009 on Environmental Protection and Management [UndangUndang Nomor 32 Tahun 2009 tentang Perlindungan dan Pengelolaan Lingkungan Hidup].

Law Number 13 of 2003 on Manpower [Undang-Undang Nomor 13 Tahun 2003 tentang Ketenagakerjaan].

Elucidation of Presidential Regulation Number 44 of 2016 on Lists of Business Fields that are Closed to and Business Fields that are Open with Conditions to Investment [Lampiran Peraturan Presiden Nomor 44 Tahun 2016 tentang Daftar Bidang Usaha yang Tertutup dan Bidang Usaha yang Terbuka dengan Persyaratan di Bidang Penanaman Modal].

The Consideration of The Ministry of Environment and Forestry Decree No P.102/Menlhk/Setjen/kum.1/12/2016 on Guidelines for the Arrangement of Environmental Evaluation Documents for Companies that Have Commercial Licenses but Not Have Environmental Documents [Bagian Menimbang Peraturan Menteri Lingkungan Hidup dan Kehutanan Republik Indonesia Nomor P.102/Menlhk/Setjen/kum.1/12/2016 tentang Pedoman Penyusunan Dokumen 
Lingkungan Hidup Bagi Usaha dan/atau Kegiatan Yang Telah Memiliki Izin Usaha dan/atau Kegiatan Tetapi Belum Memiliki Dokumen Lingkungan Hidup].

Decision of the Constitutional Court of Indonesia No. 21, 22/PUU-V/2007, 25 March 2008 [Putusan Mahkamah Konstitusi No. 21/PUU-V/2007 tentang Pengujian UU No. 25 Tahun 2007 tentang Penanaman Modal]. 